\title{
Selected Factors of Innate Immunity in Healthy Individuals with S. aureus Nasal Carriage
}

\section{Tomasz M. Karpiński', Zbigniew Żaba², Izabela Chudzicka-Strugała', Anna K. Szkaradkiewicz ${ }^{3}$, Agata Jaworska ${ }^{1}$, Agnieszka Zeidler ${ }^{1}$, Ewa Andrzejewska ${ }^{1}$ and Andrzej Szkaradkiewicz ${ }^{1 *}$}

\author{
${ }^{1}$ Department of Medical Microbiology, Poznan University of Medical Sciences, Poznań, Poland, ${ }^{2}$ Department of Teaching \\ Anaesthesiology and Intensive Therapy, Poznan University of Medical Sciences, Poznań, Poland, ${ }^{3}$ Department of \\ Conservative Dentistry and Periodontology, Poznan University of Medical Sciences, Poznań, Poland
}

Nasal carriage of Staphylococcus aureus represents a well-defined factor of risk involving community and hospital-acquired infections. Recently a significance of several host factors has been pointed out and, in particular, of immune determinants in nasal S. aureus colonization. Therefore, this study aimed at analysis of manifestation involving manifestation in the nasal secretions of important components of the host innate immunity - human beta-defensin-2 (HBD-2), lysozyme (Ly), and interferon-gamma

OPEN ACCESS

Edited by: Hao Shen,

University of Pennsylvania, USA

Reviewed by:

Dane Parker

Columbia University, USA

Marisa Mariel Fernandez,

University of Buenos Aires, Argentina

${ }^{*}$ Correspondence: Andrzej Szkaradkiewicz szkaradkiewicza@poczta.onet.pl

Specialty section:

This article was submitted to Microbial Immunology, a section of the journal Frontiers in Microbiology

Received: 15 February 2016 Accepted: 21 March 2016 Published: 31 March 2016

Citation: Karpiński TM, Żaba Z, Chudzicka-Strugała I, Szkaradkiewicz AK, Jaworska A,

Zeidler A, Andrzejewska E and Szkaradkiewicz A (2016) Selected Factors of Innate Immunity in Healthy Individuals with S. aureus Nasal Carriage. Front. Microbiol. 7:453. doi: 10.3389/fmicb.2016.00453 $(\mathrm{IFN}-\gamma)$ in healthy individuals and in persons with persistent carriage of $S$. aureus. The studies were conducted in two groups of healthy volunteers, encompassing non-carriers (group 1) or persistent carriers of $S$. aureus (group 2). Elisa assays were employed to evaluate levels of HBD-2, Ly, and IFN- $\gamma$ in nasal secretions of the examined donors. In S. aureus carriers a significant variability of HBD-2 levels was detected, corresponding to, respectively, the high (averaging at $1.46 \mathrm{ng} / \mathrm{ml}$ ) and the low (averaging at $0.13 \mathrm{ng} / \mathrm{ml}$ ) secretory response of the defensin. The level of Ly in $S$. aureus carriers averaged at $1.46 \mu \mathrm{g} / \mathrm{ml}$ and it manifested no significant difference as compared to that noted in non-carriers. In turn, concentrations of IFN- $\gamma$ in nasal secretions in the group of carriers of $S$. aureus amounted on the average to $81.7 \mathrm{pg} / \mathrm{ml}$ and they were 1.3-fold higher that in the group of non-carriers. The obtained results allow to conclude that IFN- $\gamma$ secretion by the nasal cavity-colonizing $S$. aureus remains quantitatively insufficient to eliminate the pathogen. Nevertheless, a significant increase in levels of this host factor may be important for restriction of the staphylococcal colonization and protection against development of an invasive infection. In turn, the role of HBD-2 and Ly in inactivation of the colonizing $S$. aureus remains doubtful.

\footnotetext{
Keywords: Staphylococcus aureus, nasal carriage, human beta-defensin-2 (HBD-2), lysozyme (Ly), interferongamma (IFN- $\gamma$ )
}

\section{INTRODUCTION}

Staphylococcus aureus represents one of the most frequently occurring community and hospitalacquired pathogens (Wertheim et al., 2004; Verhoeven et al., 2014). The vestibulum nasi is the primary reservoir of $S$. aureus in humans, and nasal carriage has been related to an increased risk of staphylococcal disease (Wertheim et al., 2005; Verhoeven et al., 2014). The nasal strains 
S. aureus originating from carriers were demonstrated also to carry toxin genes, most frequently the gene coding for toxic shock syndrome toxin 1 (TSST-1) - tst (Mehrotra et al., 2000). Moreover, persistent carriers exhibited higher than in noncarriers serum anti-staphylococcal antibodies targeted at TSST-1 (Verkaik et al., 2009). At present, two categories of nasal carriers are distinguished, involving persistent and non-persistent carries, respectively (Van Belkum et al., 2009). The persistent nasal carriage of $S$. aureus is appraised to affect around $20-30 \%$ of the whole population, in Poland on the average $28 \%$ of healthy adults (Wertheim et al., 2005; Chudzicka-Strugała et al., 2015). In the process of $S$. aureus nasal colonization various bacterial factors play role, mainly adhesion molecules such as surface components, including clumping factor B (ClfB) and cell wall teichoic acids (Mulcahy et al., 2012; Weidenmaier et al., 2012). Nevertheless, genetic investigations indicate that there exists no specific bacterial factor linked to persistent nasal carriage of S. aureus (Lamers et al., 2011). However, a significance of certain bacterial species in the normal flora was pointed out for reduction of S. aureus nasal colonization (Frank et al., 2010). In parallel, involvement of host innate immunity, in particular of defensins and of the already well known antibacterial peptides was accepted in reduction of S. aureus nasal carriage (Van Belkum et al., 2007; Sollid et al., 2014). Nevertheless, the role of this defensin and of the other important determinants of innate immunity still remains unclear in the nasal $S$. aureus colonization.

Therefore, this study aimed at analysis of the presence in the nasal secretions of human beta-defensin-2 (HBD-2), lysozyme (Ly), and interferon-gamma (IFN- $\gamma$ ) in healthy individuals and in persons with persistent nasal carriage of $S$. aureus.

\section{MATERIALS AND METHODS}

\section{Patients}

The studies were performed in the Department of Medical Microbiology, Poznań University of Medical Sciences, over a period of 2 years (2014-2015). All the research protocols were reviewed and approved by the Ethics Committee at the Poznan University of Medical Sciences, Poland. All subjects gave written informed consent in accordance with the Declaration of Helsinki. Sixty persons were qualified for the studies, in two research groups. The first group (group 1) included 30 persons (20 womens and 10 mens), 19-24 years of age, classified as noncarriers of $S$. aureus. Group 2 comprised 30 persons (18 womens and 12 mens), 20-24 years of age, confirmed persistent $S$. aureus nasal carriers. For the carriers, nasal cultures were positive for $S$. aureus on two occasions during a minimum interval of 3 months, according to Panierakis et al. (2009). The volunteers did not include health care workers. The investigated groups included no individuals with current infection or reporting chronic diseases or persons reporting in anamnesis genetic diseases. Moreover, persons with anatomic alterations in the nose, smokers, individuals administered with oral contraceptives and i.v., drug users were excluded. Within the previous 2 weeks, none of the patients in the mentioned groups was administered with antibiotics/chemotherapeutic agents locally or systemically.
Additionally, dental examinations of patients failed to find any potential infection foci in the oral cavity. The investigated material involved nasal swab samples for detection of bacterial carriage and nasal secretions for estimation of levels of HBD-2, Ly, and IFN- $\gamma$. Nasal secretions were collected by vacuum-aided suction without chemical stimulation, as earlier described (Cole et al., 1999). Gentle manipulation of a rubber-tipped vacuum device inside the nasal passageways stimulated release of nasal fluid. Nasal secretions were stored at $-20^{\circ} \mathrm{C}$ until further analyses were performed.

\section{Detection of S. aureus}

The bacteria were isolated on sheep blood agar within $20-24 \mathrm{~h}$ at a temperature of $37^{\circ} \mathrm{C}$ in aerobic conditions. The developed colonies were subsequently identified using conventional techniques (colony morphology, evaluation of haemolysis, staining according to Gram, production of coagulase, catalase, ability to decompose mannitol in Chapman medium). Identification of $S$. aureus was conducted using the automated system ATB with the application of ID 32 Staph strips (bioMérieux). Moreover, presence of $S$. aureus was confirmed using PCR. All strains of $S$. aureus proved to be methicillinsensitive (MSSA).

\section{Detection of $S$. aureus using PCR}

DNA was isolated from the obtained isolates of $S$. aureus clinical strains. At first, the samples were digested with lysostaphin (10 $\mu \mathrm{l}$ of $1 \mathrm{mg} / \mathrm{ml}$ solution) and incubating them for $10 \mathrm{~min}$ at a temperature of $37^{\circ} \mathrm{C}$. Subsequently, for the isolation of DNA, Swab kits (A\&A Biotechnology) were used. The isolation of DNA was conducted as recommended by the manufacturer. The purified DNA was stored at $-20^{\circ} \mathrm{C}$ until further analyses were performed. In PCR studies the following oligonucleotide primers were used according to Martín-López et al. (2004): femB1 5'-TTACAGAGTTAACTGTTACC-3' and femB2 $5^{\prime}$-ATACAAATCCAGCACGCTCT-3' from $\mathrm{femB}$ gene of $S$. aureus. PCR reaction was conducted in $25 \mu \mathrm{l}$ of mixture consisting of $1 \mathrm{x}$ reaction buffer [10 mM Tris- $\mathrm{HCl}(\mathrm{pH} 8.3)]$, $2.5 \mathrm{mM} \mathrm{MgCl}_{2}, 0.2 \mathrm{mM}$ of each of the four dNTPs, $1.25 \mathrm{U}$ of Taq DNA polymerase, $0.2 \mu \mathrm{M}$ of each primer and $1 \mu \mathrm{l}$ of templete DNA. The PCR reaction was conducted in the Mastercycler Pro $S$ thermocycler (Eppendorf) with the following thermal cycling profile: an initial denaturation at $94^{\circ} \mathrm{C}$ for $4 \mathrm{~min}$, denaturation at $94^{\circ} \mathrm{C}$ for $45 \mathrm{~s}$, annealing at $50^{\circ} \mathrm{C}$ for $45 \mathrm{~s}$, and extension at $72^{\circ} \mathrm{C}$ for $60 \mathrm{~s}$, ending with a final extension step at $72^{\circ} \mathrm{C}$ for $10 \mathrm{~min}$. The number of cycles in PCR reaction was 30 . The PCR product was subjected to electrophoresis in $1 \%$ agarose gel and the result was recorded following staining with ethidine bromide. A positive result was accepted to involve presence of PCR reaction product of $651 \mathrm{bp}$ in size.

\section{Elisa Tests}

Levels of HBD-2, Ly, and IFN- $\gamma$ in nasal secretions were estimated by Elisa technique using kits of Human Beta Defensin 2 (Alpha Diagnostic), Lysozyme Elisa Kit (Sigma), and Human IFN- $\gamma$ High Sensitivity Elisa (eBioscience). Sensitivity of the applied tests amounted to $5 \mathrm{pg} / \mathrm{ml}, 0.021 \mathrm{ng} / \mathrm{ml}$ and $0.06 \mathrm{pg} / \mathrm{ml}$, 
respectively. The tests were performed as recommended by the manufacturers. Values of absorbance, depending on the estimated substance, were read using Reader 250 (bioMérieux). The results were obtained from standard curves. Every test was performed three times and the presented result involved mean of the estimations.

\section{Data Analysis}

Results obtained in the studies were subjected to statistical analysis employing the computer Statistica 8 software for the Windows operational system. In comparative analysis of studied factors in the groups, the nonparametric test of MannWhitney and Kruskal-Wallis with Dunn's was employed. The relationships with $P$-values higher than 0.05 were considered insignificant.

\section{RESULTS}

In the group 1 of healthy volunteers (non-carriers $S$. aureus) in $26(87 \%)$ persons mean level of HBD-2 amounted to $68.42 \pm 18.06 \mathrm{pg} / \mathrm{ml}$, while in $4(13 \%)$ persons the level was significantly elevated, amounting to $1352.75 \pm 206.47 \mathrm{pg} / \mathrm{ml}$. In group 2 two categories of results were obtained: in $22(73 \%)$ carriers of $S$. aureus the mean level of HBD-2 was very high and it amounted to $1456.23 \pm 202.68 \mathrm{pg} / \mathrm{ml}$, while in $8(27 \%)$ persons concentrations of the defensin were low, averaging at $132.13 \pm 15.82 \mathrm{pg} / \mathrm{ml}$. In parallel, the results proved to be statistically higher than those detected in $87 \%$ non-carriers. The obtained results were summed up in Table $\mathbf{1}$ and, graphically, in Figure 1.

In group 1 of healthy volunteers (non-carriers $S$. aureus) the mean level of Ly amounted to $1.46 \pm 0.34 \mu \mathrm{g} / \mathrm{ml}$, while in group 2 of $S$. aureus carriers the mean level amounted to $1.29 \pm 0.30 \mu \mathrm{g} / \mathrm{ml}$. Levels of the enzyme showed no significant inter-group difference; they were presented in Table $\mathbf{2}$ and in Figure 2 .

In group 1 of healthy volunteers (non-carriers of $S$. aureus) the mean level of IFN- $\gamma$ was $63.8 \pm 14.2 \mathrm{pg} / \mathrm{ml}$, while in the group 2 of $S$. aureus carriers it amounted to $81.7 \pm 14.8 \mathrm{pg} / \mathrm{ml}$. In the latter group levels of IFN- $\gamma$ proved to be significantly higher than those in group 1 of non-carriers. The results were summed up in Table 2 and in Figure 3.

TABLE 1 | Levels of HBD-2 in the nasal secretions in non-carriers Staphylococcus aureus (group 1) and in carriers of S. aureus (group 2).

\begin{tabular}{|c|c|c|c|}
\hline \multirow[t]{2}{*}{ Studied defensin } & \multicolumn{2}{|c|}{$\begin{array}{l}\text { Mean values } \pm \text { SD } \\
\text { (minimun-maximum) }\end{array}$} & \multirow[t]{2}{*}{$\begin{array}{l}P \text { between } \\
\text { groups }\end{array}$} \\
\hline & $\begin{array}{c}\text { group } 1 \\
n=30\end{array}$ & $\begin{array}{c}\text { group } 2 \\
n=30\end{array}$ & \\
\hline \multirow[t]{2}{*}{ HBD-2 (pg/ml) } & $\begin{array}{c}n=26 \\
68.42 \pm 18.06 \\
(32.2-103.8)\end{array}$ & $\begin{array}{c}n=8 \\
132.13 \pm 15.82 \\
(108.7-156.4)\end{array}$ & $<0.0001$ \\
\hline & $\begin{array}{c}n=4 \\
1352.75 \pm 206.47 \\
(1131-1587)\end{array}$ & $\begin{array}{c}n=22 \\
1456.23 \pm 202.68 \\
(1121-1775)\end{array}$ & $>0.05$ \\
\hline
\end{tabular}

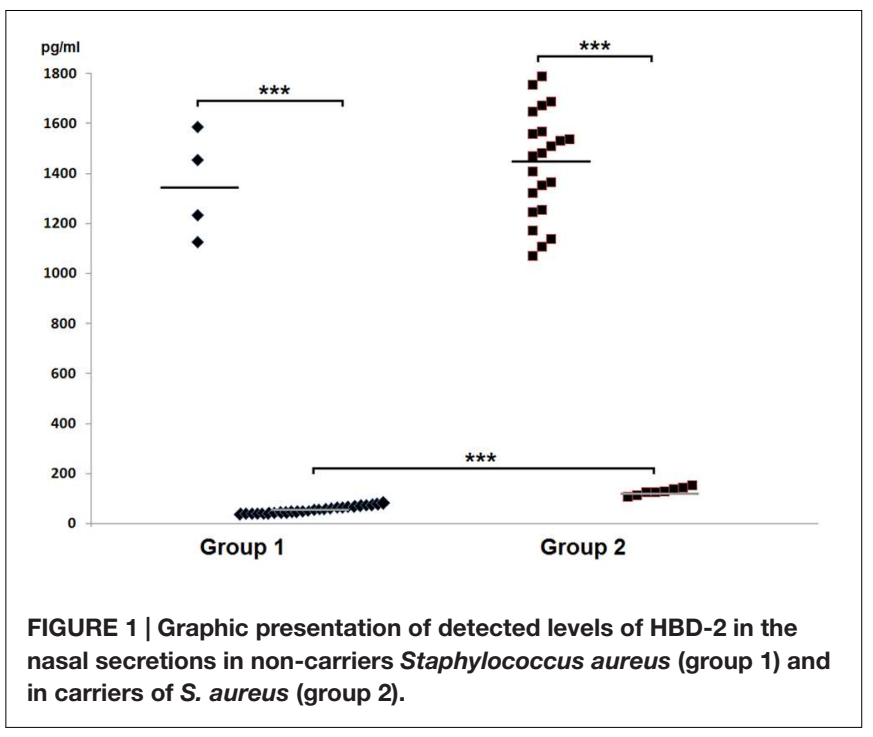

\section{DISCUSSION}

Several host factors which spontaneously exert anti-microbial activity create innate immunity against infections (Boman, 2000; Brown et al., 2014). In this study we conducted investigations related to presence of three important determinants of innate immunity, HBD-2, Ly, and IFN- $\gamma$ in nasal fluids of healthy persistent carriers of $S$. aureus and in non-carriers.

HBD-2 involves an antimicrobial peptide, produced mainly by skin keratinocytes and respiratory epithelial cells in response to infection and inflammation (Schneider et al., 2005). Currently, the peptide is thought to form the first line of local defense at the mucosal surface (Guaní-Guerra et al., 2010). In analysis of HBD-2 manifestation in nasal fluids originating from the examined volunteers we obtained two categories of results both in the group of carriers of S. aureus, and among non-carriers. In the latter, in around $87 \%$ individuals we detected low levels of the defensin, not exceeding $0.1 \mathrm{ng} / \mathrm{ml}$, while in around $13 \%$ volunteers level of the peptide in nasal fluids was high, exceeding $1 \mathrm{ng} / \mathrm{ml}$. The high levels of HBD-2 were detected also in around $73 \%$ carriers of $S$. aureus. On the other hand, in around $27 \%$ of the remaining carriers levels of the defensin remained within low concentrations even if they were significantly higher than those detected in $87 \%$ non-carriers. The data correspond with

TABLE 2 | Levels of Ly and IFN- $\gamma$ in the nasal secretions in non-carriers $S$. aureus (group 1) and in carriers of $S$. aureus (group 2).

\begin{tabular}{lccc}
\hline Studied factor & \multicolumn{2}{c}{$\begin{array}{c}\text { Mean values } \pm \text { SD } \\
\text { (minimum-maximim) }\end{array}$} & $\begin{array}{c}\boldsymbol{P} \text { between } \\
\text { groups }\end{array}$ \\
\cline { 2 - 3 } & $\begin{array}{c}\text { group 1 } \\
\boldsymbol{n}=\mathbf{3 0}\end{array}$ & $\begin{array}{c}\text { group 2 } \\
\boldsymbol{n}=\mathbf{3 0}\end{array}$ & \\
\hline $\mathrm{Ly}(\mu \mathrm{g} / \mathrm{ml})$ & $1.29 \pm 0.30$ & $1.46 \pm 0.34$ & $>0.05$ \\
& $(0.72-1.94)$ & $(0.88-2.12)$ & \\
$\mathrm{IFN}-\gamma(\mathrm{pg} / \mathrm{ml})$ & $63.8 \pm 14.2$ & $81.7 \pm 14.8$ & $<0.0001$ \\
& $(42.3-97.6)$ & $(50.7-112.2)$ &
\end{tabular}




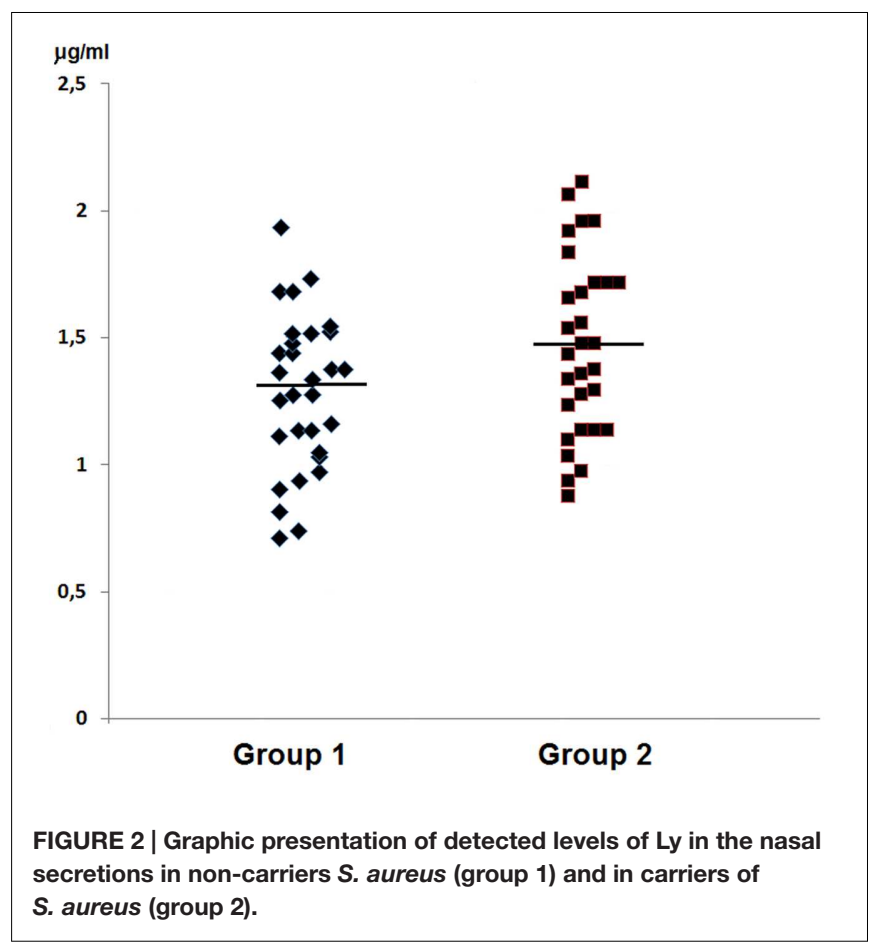

those obtained by Cole et al. (2001), who documented high concentrations of HBD-2 in nasal fluids of persistently colonized carriers. However, the quoted authors failed to provide the number of donors in whose nasal fluids the peptide was analyzed and the employed by them ELISA test showed low sensitivity $(0.125 \mathrm{ng} / \mathrm{ml})$. Therefore, results of their paper can only partially be compared to our results. The detected by us in persistent

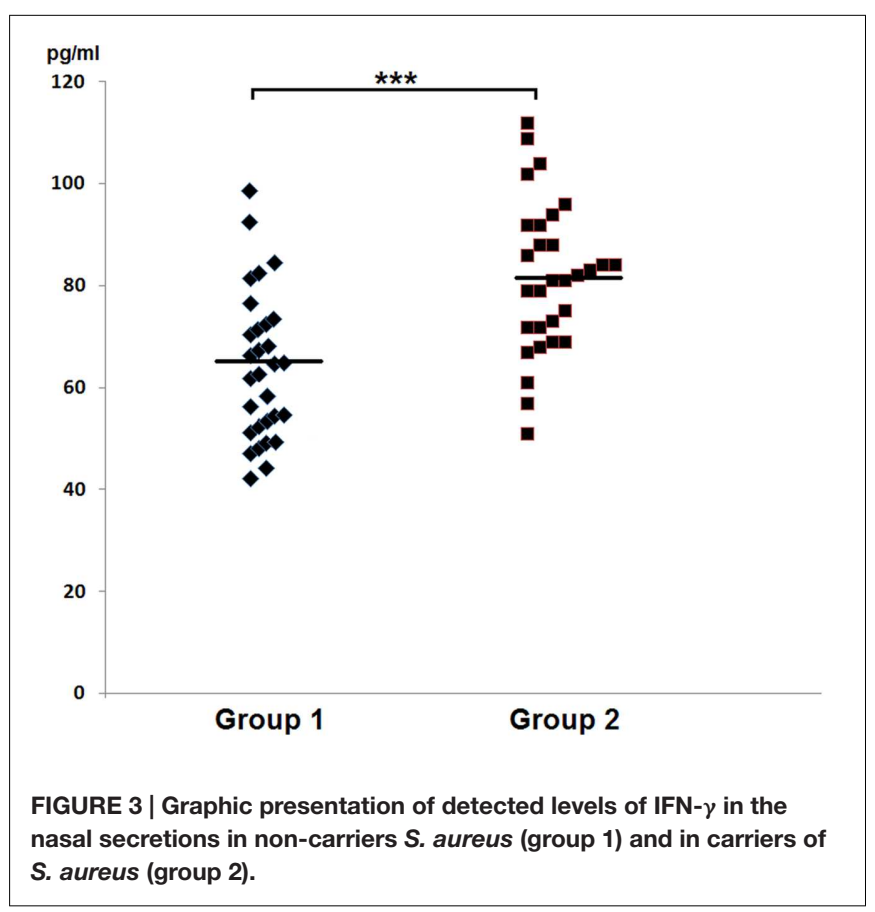

S. aureus carriers significant variability in levels of HBD-2, may represent a result of the presence among healthy individuals of "high responders" and "low responders," depending on the level of induction involving expression of HBD-2 genes in nasal epithelial cells. Such a conclusion seems to be probable in view of results obtained by Nurjadi et al. (2013), who demonstrated associations between genetic polymorphisms, $\beta$-defensin (HBD1 and HBD-3) expression, and persistent $S$. aureus nasal carriage. A suppressive effect is also possible, exerted in the carriers by $S$. aureus strains on expression of the defensin, as suggested by Quinn and Cole (2007). The presented data allow to assume that the action of $\mathrm{HBD}-2$ against the colonizing $S$. aureus remains ineffective. In contrast to this suggestion seem to argue studies of Routsias et al. (2010), who demonstrated in vitro high bactericidal efficacy of the defensin against $S$. aureus clinical strains. Significance of the studies, however, was reduced by interpretation because the quoted authors used in their experiments HBD-2 concentrations significantly higher than the defensin levels detected by us in the nasal fluids. Moreover, studies on healthy skin specimens originating from patients with persistent nasal carriage of $S$. aureus and from noncarriers, conducted by Zanger et al. (2011) indicated that nasal colonization by the pathogen was promoted by a deficit in HBD3. Thus, the significantly elevated concentrations of HBD-2 in nasal secretions of carriers may represent just a sequel of local inflammatory response against colonizing S. aureus. In turn, the high levels of the defensin detected in this study in some noncarriers may reflect its induction by transient nasal microflora, and the Gram-negative bacilli in particular. Stimulation of HBD2 expression by bacterial LPS is already well known (GuaníGuerra et al., 2010).

Lysozyme represents a polypeptide manifesting enzymatic activity (muramidase activity), hydrolysing $\beta-1,4$ glycosidic bonds between $\mathrm{N}$-acetylmuramic acid and $\mathrm{N}$-acetylglucosamine of bacterial peptidoglycan (Dziarski, 2004). The enzyme creates an important component of the host innate immunity. It is present ubiquitously in various human tissues and secretions, exhibiting antimicrobial activities against different microorganisms (Dumoulin et al., 2007). Ly was first reported in nasal secretions by Fleming (1922). In our study we have found that nasal fluids of healthy donors contain Ly levels within the range of $0.7-1.9 \mu \mathrm{g} / \mathrm{ml}$, manifesting no significant difference as compared to nasal fluids in carriers of $S$. aureus. It is difficult to compare the results to those obtained in earlier studies (Raphael et al., 1989; Noble, 2002), the authors of which estimated Ly activity using a turbidimetric assay, based on the enzymatic hydrolysis of bacterial cell walls. Therefore, the obtained data allow to conclude that Ly does not prevent against nasal carriage of $S$. aureus. The conclusion is supported by studies pointing to high resistance of peptidoglycan of S. aureus to lytic activity of Ly (Pushkaran et al., 2015). However, a non-lytic mechanism of the enzyme activity is also known, related to its cationic and hydrophobic properties, which results in bacterial autolysis (Masschalck et al., 2002). Chen et al. (2005) in their in vitro analysis of Ly action demonstrated its antibacterial activity toward $S$. aureus and, moreover, demonstrated a synergism of Ly and HBD-2 actions. 
However, the phenomenon manifested statistically significant effects only in an acidic milieu ( $\mathrm{pH} 4.6)$, while nasal fluids manifest a neutral or slightly alkaline $\mathrm{pH}$ (Lee et al., 2009). In the context of the data it can be concluded that Ly concentrations in nasal fluid are not sufficient to secure effective elimination of the colonizing $S$. aureus.

IFN- $\gamma$ represents a typical cytokine, produced mainly by lymphocytes T and NK (Young and Hardy, 1995). The cytokine plays a central role in the innate immunity to infection. It also exerts a strong monocyte/macrophage-stimulating effect, activating phagocytosis and mechanisms for intracellular killing of pathogens (Schroder et al., 2004). In this study, using high sensitivity Elisa test for the first time we have documented IFN- $\gamma$ estimations in nasal fluids in carriers of $S$. aureus. The detected by us levels of the cytokine proved to be comparable to results recently obtained by König et al. (2015), using a commercial immunofluorescence multiplexed assay. Also, the concentrations of IFN- $\gamma$ detected in nasal secretions of $S$. aureus carriers were on the average 1.3-fold higher that those present in non-carriers. The results correspond to those obtained in the recently published studies of Brown et al. (2015) on a mouse in vitro model and in vitro human estimations which showed that $S$. aureus enhanced IFN $-\gamma$ response, which might be followed by an augmented microbicidal activity of phagocytes and by elimination of the pathogens. In this context, persistence of $S$. aureus carriage may be linked to an insufficient increase of IFN- $\gamma$ level to clear the colonizing pathogen. Moreover, a defect in phagocyte function is also possible, even if in anamnesis the examined individuals provided no respective indications.

\section{REFERENCES}

Boman, H. G. (2000). Innate immunity and the normal microflora. Immunol. Rev. 173, 5-16. doi: 10.1034/j.1600-065X.2000.917301.x

Brown, A. F., Leech, J. M., Rogers, T. R., and McLoughlin, R. M. (2014). Staphylococcus aureus colonization: modulation of host immune response and impact on human vaccine design. Front. Immunol. 4:507. doi: 10.3389/fimmu.2013.00507

Brown, A. F., Murphy, A. G., Lalor, S. J., Leech, J. M., O’Keeffe, K. M., Mac Aogáin, M., et al. (2015). Memory Th1 cells are protective in invasive Staphylococcus aureus infection. PLoS Pathog. 11:e1005226. doi: 10.1371/journal.ppat.1005226

Chen, X., Niyonsaba, F., Ushio, H., Okuda, D., Nagaoka, I., Ikeda, S., et al. (2005). Synergistic effect of antibacterial agents human beta-defensins, cathelicidin LL37 and lysozyme against Staphylococcus aureus and Escherichia coli. J. Dermatol. Sci. 40, 123-132. doi: 10.1016/j.jdermsci.2005.03.014

Chudzicka-Strugała, I., Karpiński, T. M., Sikora, A., Zeidler, A., and Szkaradkiewicz, A. (2015). "Slime production and agr genes expression in S. aureus strains isolated from healthy students in Poland," in Proceedings of the 25th European Congress of Clinical Microbiology and Infectious Diseases, 25-28 April 2015, Copenhagen, EV0345.

Cole, A. M., Dewan, P., and Ganz, T. (1999). Innate antimicrobial activity of nasal secretions. Infect. Immun. 67, 3267-3275.

Cole, A. M., Tahk, S., Oren, A., Yoshioka, D., Kim, Y. H., Park, A., et al. (2001). Determinants of Staphylococcus aureus nasal carriage. Clin. Diagn. Lab. Immunol. 8, 1064-1069.

Dumoulin, M., Johnson, R. J. K., Bellotti, V., and Dobson, C. M. (2007). "Human lysozyme," in Protein Misfolding, Aggregation, and Conformational Diseases, eds V. N. Uversky and A. L. Fink (New York, NY: Springer), 285-308.

Dziarski, R. (2004). Peptidoglycan recognition proteins (PGRPs). Mol. Immunol. 40, 877-886. doi: 10.1016/j.molimm.2003.10.011
However, the elevated level of IFN- $\gamma$ may at least in part mediate a microbicidal activity, preventing against spread of the infection.

\section{CONCLUSION}

The presented data indicate that the detected by us induction of IFN- $\gamma$ secretion by nasal cavity-colonizing $S$. aureus remained quantitatively insufficient to eliminate the pathogen. Nevertheless, the significant increase in the host factors may be of importance for a reduced staphylococcal colonization and protection against spread of the invasive infection. On the other hand, involvement of HBD-2 and Ly in inactivation of the colonizing $S$. aureus seems doubtful.

\section{AUTHOR CONTRIBUTIONS}

Conceived and designed the experiments: TK and AS. Material collection: ZŻ, IC-S, and EA. Performed the experiments: TK, AS, AJ, and AZ. Analyzed the data: TK, AS, and AS. Wrote the manuscript: TK and AS.

\section{ACKNOWLEDGMENT}

The research was supported by Poznań University of Medical Sciences, Poland (504-01-02206316-7/109-02658).

Fleming, A. (1922). On a remarkable bacteriolytic element found in tissues and secretions. Proc. R. Soc. B Biol. Sci. 93, 306-317. doi: 10.1098/rspb.1922.0023

Frank, D. N., Feazel, L. M., Bessesen, M. T., Price, C. S., Janoff, E. N., and Pace, N. R. (2010). The human nasal microbiota and Staphylococcus aureus carriage. PLoS ONE 5:e10598. doi: 10.1371/journal.pone.0010598

Guaní-Guerra, E., Santos-Mendoza, T., Lugo-Reyes, S. O., and Terán, L. M. (2010). Antimicrobial peptides: general overview and clinical implications in human health and disease. Clin. Immunol. 135, 1-11. doi: 10.1016/j.clim.2009.12.004

König, K., Klemens, C., Eder, K., San Nicoló, M., Becker, S., Kramer, M. F., et al. (2015). Cytokine profiles in nasal fluid of patients with seasonal or persistent allergic rhinitis. Allergy Asthma Clin. Immunol. 11, 26. doi: 10.1186/s13223-0150093-x

Lamers, R. P., Stinnett, J. W., Muthukrishnan, G., Parkinson, C. L., and Cole, A. M. (2011). Evolutionary analyses of Staphylococcus aureus identify genetic relationships between nasal carriage and clinical isolates. PLOS ONE 6:e16426. doi: 10.1371/journal.pone.0016426

Lee, H. J., Choi, J. C., Yoon, J. H., Joe, N. S., Kim, C. H., and Kim, J. Y. (2009). The study of $\mathrm{pH}$ in nasal secretion in normal and chronic rhinosinusitis. J. Rhinol. 16, 105-109.

Martín-López, J. V., Díez-Gil, O., Morales, M., Batista, N., Villar, J., ClaverieMartín, F., et al. (2004). Simultaneous PCR detection of ica cluster and methicillin and mupirocin resistance genes in catheter-isolated Staphylococcus. Int. Microbiol. 7, 63-66.

Masschalck, B., Deckers, D., and Michiels, C. W. (2002). Lytic and nonlytic mechanism of inactivation of gram-positive bacteria by lysozyme under atmospheric and high hydrostatic pressure. J. Food Prot. 65, 1916-1923.

Mehrotra, M., Wang, G., and Johnson, W. M. (2000). Multiplex PCR for detection of genes for Staphylococcus aureus enterotoxins, exfoliative toxins, toxic shock syndrome toxin 1, and methicillin resistance. J. Clin. Microbiol. 38, 1032-1035.

Mulcahy, M. E., Geoghegan, J. A., Monk, I. R., O’Keeffe, K. M., Walsh, E. J., Foster, T. J., et al. (2012). Nasal colonisation by Staphylococcus aureus 
depends upon clumping factor B binding to the squamous epithelial cell envelope protein loricrin. PLoS Pathog. 8:e1003092. doi: 10.1371/journal.ppat. 1003092

Noble, R. E. (2002). Effect of environmental contaminants on nasal lysozyme secretions. Sci. Total Environ. 284, 263-266. doi: 10.1016/S0048-9697(01)00871-3

Nurjadi, D., Herrmann, E., Hinderberger, I., and Zanger, P. (2013). Impaired $\beta$ defensin expression in human skin links DEFB1 promoter polymorphisms with persistent Staphylococcus aureus nasal carriage. J. Infect. Dis. 207, 666-674. doi: 10.1093/infdis/jis735

Panierakis, C., Goulielmos, G., Mamoulakis, D., Maraki, S., Papavasiliou, E., and Galanakis, E. (2009). Staphylococcus aureus nasal carriage might be associated with vitamin D receptor polymorphisms in type 1 diabetes. Int. J. Infect. Dis. 13, e437-e443. doi: 10.1016/j.ijid.2009.02.012

Pushkaran, A. C., Nataraj, N., Nair, N., Götz, F., Biswas, R., and Mohan, C. G. (2015). Understanding the structure-function relationship of lysozyme resistance in Staphylococcus aureus by peptidoglycan O-acetylation using molecular docking, dynamics, and lysis assay. J. Chem. Inf. Model. 55, 760-770. doi: $10.1021 /$ ci500734k

Quinn, G. A., and Cole, A. M. (2007). Suppression of innate immunity by a nasal carriage strain of Staphylococcus aureus increases its colonization on nasal epithelium. Immunology 122, 80-89. doi: 10.1111/j.1365-2567.2007.02615.x

Raphael, G. D., Jeney, E. V., Baraniuk, J. N., Kim, I., Meredith, S. D., and Kaliner, M. A. (1989). Pathophysiology of rhinitis. Lactoferrin and lysozyme in nasal secretions. J. Clin. Invest. 84, 1528-1535. doi: 10.1172/JCI114329

Routsias, J. G., Karagounis, P., Parvulesku, G., Legakis, N. J., and Tsakris, A. (2010). In vitro bactericidal activity of human beta-defensin 2 against nosocomial strains. Peptides 31, 1654-1660. doi: 10.1016/j.peptides.2010.06.010

Schneider, J. J., Unholzer, A., Schaller, M., Schäfer-Korting, M., and Korting, H. C. (2005). Human defensins. J. Mol. Med. 83, 587-595. doi: 10.1007/s00109-0050657-1

Schroder, K., Hertzog, P. J., Ravasi, T., and Hume, D. A. (2004). Interferon-gamma: an overview of signals, mechanisms and functions. J. Leukoc. Biol. 75, 163-189. doi: $10.1189 / \mathrm{jlb} .0603252$

Sollid, J. U., Furberg, A. S., Hanssen, A. M., and Johannessen, M. (2014). Staphylococcus aureus: determinants of human carriage. Infect. Genet. Evol. 21, 531-541. doi: 10.1016/j.meegid.2013.03.020

Van Belkum, A., Emonts, M., Wertheim, H., de Jongh, C., Nouwen, J., Bartels, H., et al. (2007). The role of human innate immune factors in nasal colonization by Staphylococcus aureus. Microbes Infect. 9, 1471-1477. doi: 10.1016/j.micinf.2007.08.003
Van Belkum, A., Verkaik, N. J., de Vogel, C. P., Boelens, H. A., Verveer, J., Nouwen, J. L., et al. (2009). Reclassification of Staphylococcus aureus nasal carriage types. J. Infect. Dis. 199, 1820-1826. doi: 10.1086/ 599119

Verhoeven, P. O., Gagnaire, J., Botelho-Nevers, E., Grattard, F., Carricajo, A., Lucht, F., et al. (2014). Detection and clinical relevance of Staphylococcus aureus nasal carriage: an update. Expert Rev. Anti Infect. Ther. 12, 75-89. doi: $10.1586 / 14787210.2014 .859985$

Verkaik, N. J., de Vogel, C. P., Boelens, H. A., Grumann, D., Hoogenboezem, T., Vink, C., et al. (2009). Anti-staphylococcal humoral immune response in persistent nasal carriers and noncarriers of Staphylococcus aureus. J. Infect. Dis. 199, 625-632. doi: 10.1086/596743

Weidenmaier, C., Goerke, C., and Wolz, C. (2012). Staphylococcus aureus determinants for nasal colonization. Trends Microbiol. 20, 243-250. doi: 10.1016/j.tim.2012.03.004

Wertheim, H. F., Melles, D. C., Vos, M. C., van Leeuwen, W., van Belkum, A., Verbrugh, H. A., et al. (2005). The role of nasal carriage in Staphylococcus aureus infections. Lancet Infect. Dis. 5, 751-762. doi: 10.1016/S1473-3099(05) 70295-4

Wertheim, H. F., Vos, M. C., Ott, A., van Belkum, A., Voss, A., Kluytmans, J. A., et al. (2004). Risk and outcome of nosocomial Staphylococcus aureus bacteraemia in nasal carriers versus non-carriers. Lancet 364, 703-705. doi: $10.1016 /$ S0140-6736(04)16897-9

Young, H. A., and Hardy, K. J. (1995). Role of interferon-gamma in immune cell regulation. J. Leukoc. Biol. 58, 373-381.

Zanger, P., Nurjadi, D., Vath, B., and Kremsner, P. G. (2011). Persistent nasal carriage of Staphylococcus aureus is associated with deficient induction of human beta-defensin 3 after sterile wounding of healthy skin in vivo. Infect. Immun. 79, 2658-2662. doi: 10.1128/IAI.00101-11

Conflict of Interest Statement: The authors declare that the research was conducted in the absence of any commercial or financial relationships that could be construed as a potential conflict of interest.

Copyright (c) 2016 Karpiński, Żaba, Chudzicka-Strugała, Szkaradkiewicz, Jaworska, Zeidler, Andrzejewska and Szkaradkiewicz. This is an open-access article distributed under the terms of the Creative Commons Attribution License (CC BY). The use, distribution or reproduction in other forums is permitted, provided the original author(s) or licensor are credited and that the original publication in this journal is cited, in accordance with accepted academic practice. No use, distribution or reproduction is permitted which does not comply with these terms. 